\title{
Women Types in To the Lighthouse and Mrs. Dalloway
}

\begin{abstract}
Virginia Woolf lived in an era in which the traditional repression was intensive on women. As Woolf grew up in an intellectual environment she was not insensible to traditional repression on women. She paid attention to this topic through literature, the most popular communication device of her time. There are certain women types in her novels. Some of them concede the sanctions of tradition, some of them are uncomfortable with traditions but non-reactive as well. And there are some women characters who defy the sanctions of tradition. This study focuses on three female characters in two novels, To the Lighthouse and Mrs. Dalloway. Among these characters Mrs. Ramsay embraces the role the society deems her worthy of as a housewife. Mrs. Dalloway is not satisfied with her role as a housewife, however; despite her reluctance she still keeps up with requirements of society. And finally favourite character of Woolf, Lily Briscoe, defies the sanctions of society.
\end{abstract}

Key Words: Woman, Tradition, Mrs. Ramsay, Mrs. Dalloway, Lily Briscoe.

\section{To the Lighthouse ve Mrs. Dalloway'de Kadın}

\section{Özet}

Virginia Woolf'un yaşadı̆̆ dönem kadın üzerindeki geleneksel baskının yoğun bir şekilde yaşandığı bir zamana denk gelir. Entelektüel bir çevrede yetişen Woolf, bir kadın olarak bu baskllara duyarsız kalmaz. Bu konuya kendi zamanındaki en yaygın iletişim aracı olan edebiyatla değinir. Romanlarında kendi çağının kadınının sorunlarını usta bir dille ele alır. Woolf romanlarında çeşitli konumlardaki kadın karakterler bulunmaktadır. Bu karakterler içinde geleneklerin öngördüğü rolü benimseyen, benimsemeyen veya geleneklere tamamen başkaldıran karakterler de vardır. Bu çalışmada Woolf'un To The Lighthouse ve Mrs. Dalloway adll romanlarındaki üç kadın karakter ele alınmaktadır. Bu karakterlerden Mrs. Ramsay geleneksel kadın rolünü benimsemiş bir kişilik sergilerken, Mrs. Dalloway geleneklerin öngördüğ̈̈ sosyal konumundan hoşnutsuz bir karakterdir. Woolf'un gözde karakteri olan Lily Briscoe ise geleneklere başkaldıran bir kişiliktir.

Anahtar kelimeler: Kadın, Gelenek, Mrs. Ramsay, Mrs. Dalloway, Lily Briscoe

${ }^{1}$ Yrd. Doç. Dr., Van Yüzüncü Y1l Üniversitesi, Edebiyat Fakültesi. hanedan65@yahoo.com 


\section{Introduction}

At the beginning of the twentieth century the women were still being confined to a limited intellectual area. Being a good housewife was the ideal role envisaged for women. The intellectual existence was not encouraged by the society. Virginia Woolf as a feminist writer appears as an important figure defying the social roles imposed to women. In this respect her support to women's rights movements can be observed in her literary studies. This study focuses on To the Lighthouse and Mrs. Dalloway among her works. Certain women characters of these works reflect transparently the era and procure a clear understanding of social condition of women in that time. Mrs. Ramsay, Lily Briscoe and Mrs. Dalloway provide essential data to be scrutinized in scope of this study.

If women's historical struggle to gain their rights is classified in three stages each of the aforementioned women will symbolize a stage of the process. The first stage is the passive stage which is identified with Mrs. Ramsay who embraces the role the society deems her worthy of as a housewife. The second stage is awakening which is represented by Mrs. Dalloway who is not satisfied with her role as a housewife. Despite her reluctance she still keeps up with requirements of society. And finally Lily Briscoe is at the third stage of the process and she defies the sanctions of society. Woolf represents Lily as a role model for women and she defies the patriarchal society via this character.

Both of the novels are set in a strong male dominated environment. The woman is expected to serve to provide a comfortable setting for men. Woolf describes such woman as utterly unselfish who sacrifices herself daily. If there was a draught, she sat in it (Briggs,2005: 10). This definition comes to an agreement with Mrs. Ramsay. Mrs. Ramsay pays attention her role as a housewife. She plays her role perfectly and enjoys the life. Despite the favoured qualifications actually she is the anti-hero of Virginia Woolf. The next character, Mrs. Dalloway, comes from an upper class and her role in society is a dutiful housewife. But she is not satisfied with her role and life becomes a burden for her. And finally Lily Briscoe, who is the heroine of Woolf, comes into scene. Lily ignores the patriarchal rules and she aims to take her social role with becoming an artist. She recovers from Tansley's negative haunting ideas and by the end of the novel a newly born Lily, who is determined to achieve her ideals, appears.

Mrs. Ramsay is the first character to be focused on. To the Lighthouse is structured around Mrs. Ramsay. She is such a self sacrificing, maternal and soother that probably most of the readers would have a sense of affinity towards her. However; the glorification of such a character is sarcastic. Quite 
the contrary to general view, Mrs. Ramsay is the most undesired character of Woolf. With a good or bad grace Mrs. Ramsay functions as a representative of the repression on women. Her handicap is acquiescing the system. She does not quest the role casted to her by the society. Woolf's aim in depicting such a character is to show the undesired example. In addition to men, women also have an important role in the ongoing disadvantageous traditions against the sake of women. And women like Mrs. Ramsay make contribution to this comprehension.

Mrs. Ramsay is the idealized woman type according to Victorian values. She has perfectly adopted the roles entrusted to her by tradition. She is a splendid hostess to serve, especially to men. Her major duty is to deal with her husband's selfishness, but she finds it necessary to deal with all male egos. Some of her children mock Charles Tansley. She cannot bear incivility in men, particularly to young men (Woolf, 2002: 5).

Indeed, she had the whole of the other sex under her protection; for reasons she could not explain, for their chivalry and valour, for the fact that they negotiated treaties, ruled India, controlled finance; finally for an attitude towards herself which no woman could fail to feel or to find agreeable, something trustful, childlike, reverential; which an old woman could take from a young man without loss of dignity, and woe betide the girl-pray Heaven it was none of her daughters! - who did not feel the worth of it, and all that it implied, to the marrow of her bones! (Woolf, 2002: 5)

Mrs. Ramsay's determination to keep the whole other sex under her protection is another sarcastic situation. The physically weak one strives to protect the physically strong ones. In the above paragraph, Woolf mentions men's chivalry, valour, negotiation of treaties, ruling and controlling the finance. All necessary power to control society belongs to men. In this respect actually the ones needed to be protected are women. Women do not have any share in the power controlled by men. The more striking point is that Mrs. Ramsay curses the girls who do not feel as she does. Besides she is thankful that her daughters are not unaware of men's highness. She is happy that her daughters will follow her. Woolf's reaction is against the power monopoly of the men and as a result she aims to highlight women's useless efforts to serve them. Tansley symbolizes the patriarchy and in order to scorn the patriarchal apprehension Woolf makes a fool of Tansley, so she shows how ridiculous are the ideas he supports. It is somehow a kind of revenge from people who share the same ideas with him.

Mrs. Ramsay is a very sensitive character who feels socially responsible especially to men. She feels sympathy even to a person like Tansley who is almost a misogynist. Tansley is a self-centred, conceited person. He does not deem women worthy of intellectual activities. According to him, women cannot paint and write (Woolf, 2002: 35). His ideas haunts Lily's mind 
negatively for a long time. Mrs. Ramsay betrays womanhood and feels sympathy even to such a misogynist. Being a male covers the mistakes he commits. She is such a devoted person she finds peace only when she is no longer herself (Woolf, 2002: 46). Mrs. Ramsay's ego is a barrier for her devotion and prefers to estrange from her ego.

Mrs. Ramsay's character has a strong influence on the women around her. Minta Doyle is one of them. Minta does not fit into criteria of Victorian period women. Mrs. Ramsay's reaction to such a situation is important to understand her way of thinking; "Dear, dear, Mrs Ramsay said to herself, how did they produce this incongruous daughter? this tomboy Minta, with a hole in her stocking?" (Woolf, 2002: 41). Mrs. Ramsay dedicates herself to change Minta. Minta is influenced by her. She follows Mrs. Ramsay's wish and accepts Paul Rayley's marriage proposal. Mrs. Ramsay aims to structure Minta's life according to requirements of society. She is blissful after achieving her desire. The main source of the happiness is the success to shape another woman into an archetypal figure of tradition. As she achieves a target she looks for other potentials and she wishes same fate for Prue, her daughter. Because she believes that an unmarried woman misses the best of life (Woolf, 2002: 36). She does not quest her position in the society. She is logically lost in her social role that her perception of woman's rights became blunt.

The second character to be studied is Mrs. Dalloway. The title of the novel is the first indicator about the role deemed suitable as a housewife for a woman. Mrs. Dalloway comes from upper class and she is not supposed to do housework, nor does she supposed to work outside of the house. Her primary duty is planning and attending parties. Forbes claims that Mrs. Dalloway tries to equate the performance of this role with her identity, but her attempts to use the role as a substitute for the fixed-essentially the Victorian-sense of self she covets result in emptiness, a lack of fulfilment, and ironically, virtually no self at all (Forbes, 2005: 39). Her identity is limited to trivial social activities. Her unsatisfactory with her role is a sign of awakening from the imposed rules of tradition. Mrs. Dalloway's marriage is based on financial and prestigious concerns. Instead of following her desires, she chooses the advantageous way for her future. Her unsatisfactory shows up in the way she lives. She does not share the same room with her husband; instead she prefers to live in a small attic room with a narrow bed. Unlike Mrs. Ramsay, Mrs. Dalloway does not devote herself to sooth the selfish personality of her husband. Her choice of socially prestigious marriage brings her a double faced life, ostentation of her life on one side and repentance on the other side. In this respect Rachman brings in the question why should she, a woman with a husband that loves her, a daughter, a secure and eminent position in society, think of death? (Rachman, 1972: 9). The 
answer lies in the false choice but she is not well aware of her mistake. She is isolated and she suffers because of the trivial requirements of the life. She just struggles to fulfil the necessities of the social environment. Her inner struggle cannot be observed by others. She endures in silence. What people see is not the real Mrs. Dalloway.

Every time she gave a party she had this feeling of being something not herself, and that everyone was unreal in one way; much more real in another. It was, she thought, partly their clothes, partly being taken out of their ordinary ways, partly the background, it was possible to say things you couldn't say anyhow else, things that needed an effort; possible to go much deeper. But not for her; not yet anyhow. (Woolf, 1996: 187-188)

Here, another important difference comes up between Mrs. Ramsay and Mrs. Dalloway. Mrs. Ramsay finds peace only when she is no longer herself. However; the loss of identity disturbs Mrs. Dalloway. She is aware of the artificiality of her surroundings. What offends her is being a part of this artificiality.

The women of Victorian period are self-sacrificing and powerless. They have embraced their roles mostly. One of the female characters, Lady Burton, is a member of high society but she often suspends judgement upon men in deference to the mysterious accord in which men, but no woman, stood to the laws of the universe (Woolf, 1996: 121). Hoff interprets this approach as it is better for women to be ruled by men because men, possessors of know-how, are by nature superior and rule, the women inferior and subject (Hoff, 2009; 162). Woolf criticizes women who do not quest this apprehension. Women of that period are also supposed to be religious, however; Mrs. Dalloway does not believe. "Love and religion!...How detestable, how detestable they are!" (Woolf, 1996: 139). She believes that religion and love destroys the privacy of the soul. Since she is not a believer, Mrs. Dalloway does not have much to rest against. Life is humiliation and renunciation for her (Woolf, 1996: 184). The character level she symbolizes is another disappointment for Woolf. Woolf uses Mrs. Dalloway to represent women that do not defy the sanctions of tradition despite their discomfiture.

The third character, Lily Briscoe, will be the favourite character among all other women in both novels. Lily is the feminist figure of To the Lighthouse. She is the idealized woman model of Woolf. Her partly weak character at the beginning of novel has changed by the end of the novel. She improves her identity and skill and becomes a more qualified person by the end of the novel. As she improves her skills she becomes more selfconfident. She is a model woman figure for the women of twentieth century. Lily is one of the candidates of Mrs. Ramsay to be sacrificed for the sake of traditions. However; she resists the repression of Mrs. Ramsay and in general repression of society. Even Mrs. Ramsay appreciates her passion for 
independence. The woman in the traditional marriage of that time is in fact a kind of slave. Lily is unwilling to become a member of this slavery.

Virginia Woolf purposefully highlights the character of Lily. It can be suggested that Lily is projection of Woolf. Derbyshire's application of their names as Virginia Lily Woolf Briscoe supports this idea (Derbyshire, 1942: 359). Lily exists in all stages of the novel, from beginning to end. Her art is more important than a commanding husband. She considers marriage as a self abasement;

For at any rate, she said to herself, catching sight of the salt cellar on the pattern, she need not marry, thank Heaven: she need not undergo that degradation. She was saved from that dilution. (Woolf, 1996: 74)

Her characteristic features are just opposite of Mrs. Ramsay's. While Mrs. Ramsay glorifies the marriage, Lily takes it as degradation. Moise (2007; 230) clarifies this claim;

Her personal conflicts, evoking gender issues of a larger scale in the British public life, originate in her refusal of fulfilling socially inscribed roles-married woman, mother, the Angel of the House-presented first and foremost in the permanent confrontation with her counterpoint Mrs. Ramsay, the other compositional pillar of both Woolf's novel and the verbally manifested painting of Lily.

Lily is a woman warrior who struggles against socially inscribed rules. In this sense Mrs. Ramsay symbolizes the tradition and Lily symbolizes the revolt against tradition. Mrs. Ramsay and Lily are mostly discussed together by scholars. They represent two faces of one coin.

Lily is one of the few characters who maintain their existence by the end of To the Lighthouse. She wants to finish the painting she has started and given up for the last ten years. Despite the gained self-confidence she is still disturbed by the presence of Mr. Ramsay while painting. She can only finish the painting after his departure to the lighthouse. She is an independent and free thinking woman but she has not reached the desired level yet. Charles Tansley's degrading ideas about women still haunt her. But they have lost their intensity, so she can finally finish a painting process that has been continuing for ten years. Eventually she has reached her target and become an artist. Güneș $(1999 ; 175)$ claims that Lily examines carefully the essence of life and reality in an artistic way until she reaches a final understanding in life. Instead of becoming a slave of tradition she chooses the way of freedom. Art becomes a tool for understanding the life and the reality. 


\section{Conclusion}

At the beginning of twentieth century women even did not have the right to vote. As the Victorian period was over, women's movements have accelerated; however the improvements in woman rights have occurred gradually and it did not diffuse to all society abruptly. Virginia Woolf's application of stream of consciousness technique gives the reader a chance to observe mind of women of that period. Woolf uses three types of women to represent three groups of women of that time. Among all women, Lily Briscoe is the most favourable for the awakening of women rights. Zwerdling claims that Woolf is deeply engaged by the question of how the individual is shaped or deformed by his social environment, by how historical forces impinge on his life and shift its course, by how class, wealth, and sex help to determine his fate (Zwerdling, 1977: 69). In both novels the influence of social environment and gender are evident on the fate of female characters. Some of them concede the sanctions of tradition, some of them are uncomfortable with traditions but non-reactive as well. And finally among the group what Lily symbolizes, is a pioneer of women rights movements.

\section{References}

BRIGGS, Julia. (2005), Virginia Woolf: An Inner Life, New York, Penguin Publication.

DERBYSHIRE. S. H. (1942), "An Analysis of Mrs. Woolf's To the Lighthouse”, Reviewed work, College English, Vol. 3, No. 4, pp. 353-360.

GÜNEŞ, Ali. (1999), "Sybolism in Virginia Woolf's To the Lighthouse”, Hacettepe Üniversitesi Edebiyat Fakültesi Dergisi, Cilt: 16/ Say1: 2 / ss. 173-188.

HOFF, Molly. (2009), Virginia Woolf 's Mrs. Dalloway Invisible Presences, Clemson University Digital Press.

FORBES, Shannon. (2005), "Equating Performance with Identity: The Failure of Clarissa Dalloway's Victorian "Self" in Virginia Woolf's "Mrs. Dalloway"', The Journal of the Midwest Modern Language Association, Vol. 38, No. 1, pp. 38-50.

MOISE, Gabriella. (2007), "Abysmal Reflections in Virginia Woolf's To the Lighthouse." My Fulbright Experience Academic Years 2006/2007. Hungarian - American Commission for Educational Exchange,pp. 225-235.

RACHMAN, Shalom. (1972), “Clarissa's Attic: Virginia Woolf's Mrs. Dalloway Reconsidered", Reviewed work, Twentieth Century Literature, Vol. 18, No. 1, pp. 3-18. 
WOOLF, Virginia. (1996a), Mrs. Dalloway, Penguin Books.

WOOLF, Virginia. (2002b), To the Lighthouse, Wordsworth Classics.

ZWERDLING, Alex. (1977), "Mrs. Dalloway and the Social System", PMLA, Vol. 92, No. 1, pp. 69-82 